\title{
PENGARUH MODEL PEMBELAJARAN KOOPERATIF DAN BERPIKIR KRITIS TERHADAP KEMAMPUAN MEMBACA PEMAHAMAN (FAHMUL QIRA'AH)
}

\author{
Nur Adibatul Lutfiyyah \\ Universitas Negeri Jakarta, Indonesia \\ adiba.lutfiyyah@gmail.com \\ Endry Boeriswati \\ Universitas Negeri Jakarta, Indonesia \\ Endry.boeriswati@unj.ac.id \\ Nuruddin \\ Universitas Negeri Jakarta, Indonesia \\ zahaidarnur@gmail.com
}

Accepted: 2020-11-26, Approved: 2021-01-04, Published: 2020-01-18

\begin{abstract}
ABSTARCT
This research aims to investigate the influence of intructional models and critical thinking ability toward reading understanding ability in Arabic language outcome of students at MDT Shibyanul Muslimin Jakarta. This research is quantitative research using design treatment by level $2 \times 2$. The instrumen used to assess students critical thingking's ability is in quentionnaire form, while the instrument used to assess student's reading understanding ability in Arabic language is in the multiple choice form. The result of the research show that: (1) reading understanding ability in Arabic language outcome of students using cooperative learning tipe STAD model are higher than those reading understanding ability in Arabic language outcomes of students using cooperative learning tipe NHT models, (2) there is interaction effect between learning model and critical thinking on reading understanding ability in Arabic language outcome of students, (3) reading understanding ability in Arabic language outcome of students who has high critical thinking and using cooperative learning tipe STAD model are higher than students using cooperative learing tipe NHT model, (4) reading understanding ability in Arabic language outcome of students who has critical thinking and using cooperative learning tipe STAD model are lower than students using the cooperative learning tipe NHT models.
\end{abstract}

Keyword: ability to read comprehension (fahmul qira'ah), learning models, critical thinking 


\section{PENDAHULUAN}

Pendidik mempunyai peran penting dalam proses pembelajaran sejarah diantaranya pendidik diharapkan mampu menciptakan proses pembelajaran yang efektif, efisien dan menyenangkan bagi peserta didik sehingga peserta didik dapat mengikuti proses pembelajaran dengan baik. Upaya yang dilakukan pendidik dalam rangka mencapai tujuan pembelajaran sejarah tersebut salah satunya adalah dengan melakukan pemilihan model pembelajaran yang tepat karena model pembelajaran sangat menentukan hasil belajar peserta didik.

Berdasarkan hasil observasi awal yang telah dilakukan di MDT Shibyanul Muslimin Jakarta Utara proses pembelajaran cenderung bersifat hafalan dan ceramah satu arah sehingga pembelajaran bahasa Arab khususnya pada kemampuan membaca pemahaman kurang begitu menyentuh bagi peserta didik, pembelajaran pun terkesan monoton karena pendidik hanya menjelaskan tentang teks bacaan tanpa memberikan contoh dalam kehidupan terkini. Proses pembelajaran dikelas yang dilakukan oleh pendidik masih menggunakan model pembelajaran yang menjenuhkan bagi peserta didik karena materi yang disampaikan oleh pendidik sudah terdapat di dalam buku teks dan mengharapkan peserta didik duduk, diam, mendengarkan, mencatat dan menghafal materi-materi tersebut.

Pembelajaran bahasa khususnya
pada kemampuan membaca
pemahaman (fahmul qira'ah) bahasa
Arab seharusnya mampu menuntut
peserta didik mengembangkan
kompetensi untuk berpikir secara

kronologis dan kritis maka diperlukan suatu model pembelajaran yang kreatif dan inovatif yang diaplikasikan oleh pendidik sehingga dapat meningkatkan motivasi peserta rdidik dalam belajar bahasa khususnya pada kemampuan membaca pemahaman (fahmul qira'ah) bahasa Arab dan pada akhirnya peserta didik mendapatkan kemampuan membaca pemahaman yang baik sesuai dengan tujuan pembelajaran.

Penelitian ini perlu dilakukan untuk mengoptim alkanpada kemampuan membaca pemahaman (fahmul qira'ah) bahasa Arab peserta didik, salah satu model pembelajaran yang menarik yang diduga dapat mengoptimalkan kemampuan membaca pemahaman (fahmul qira'ah) bahasa Arab peserta didik adalah model pembelajaran kooperatif tipe STAD yang dirancang oleh Robert. E. Slavin yang mampu mengembangkan berpikir kritis peserta didik.

Pembelajaran membaca tidak semudah pembelajaran menulis, karena membaca adalah langkah awal seseorang mengenal tulisan. Prosesnya pun sulit karena pembaca harus tetap fokus dalam menjalin keterkaitan setiap huruf, kata, atau kalimat secara berkelanjutan baik sisi ucapannya maupun maknanya. Terlebih membaca bahasa Arab karena fokusnya tidak hanya kata dan kalimat tetapi juga tanda titik pada huruf, apakah di atas atau di bawah karena itu akan merubah maknanya secara total.

Membaca menurut (Alek, 2010) adalah proses memahami pesan tertulis yang menggunakan bahasa tertentu yang disampaikan oleh penulis kepada pembacanya Sedangkan menurut (Aizid, 2011), dari segi linguistik 
membaca adalah suatu penyandian kembali dan pembacaan sandi (a recording and decoding process). Membaca adalah suatu perbuatan atau tindakan yang dilakukan berdasarkan kerja sama antara beberapa keterampilan, yaitu: mengamati, memahami, dan memikirkan.

Menurut Benyamin S. Bloom dalam (Sudijono, 2011) pemahaman adalah kemampuan seseorang untuk mengerti atau memahami sesuatu setelah sesuatu itu diketahui dan di ingat. Seorang peserta didik dikatakan memahami sesuatu apabila ia dapat memberikan penjelasan atau memberi uraian yang lebih rinci tentang hal itu dengan menggunakan bahasa sendiri. Menurut (Purwanto, 2010) pemahaman atau komprehensi adalah tingkat kemampuan yang mengharapkan seseorang mampu memahami arti atau konsep, situasi, serta fakto yang diketahuinya. Dalam hal ini testee tidak hanya hafal cara verbalistis, tetapi memahami konsep dari masalah atau fakta yang ditanyakan. Dari pemaparan diatas, dapat disimpulkan bahwa pemahaman adalah label yang biasanya diterapkan untuk pemerolehan makna dari bacaan. Membaca tidak terjadi tanpa pemahaman dan pemahaman bacaan tidak tercapai jika tidak melibatkan aktivitas berpikir. Pemahaman terhadap bacaan atau teks sangat bergantung pada semua aspek yang terlibat dalam proses membaca.

Model pembelajaran kooperatif
tipe STAD $\quad$ (Student $r$ Teams
Achievement $\quad$ Division)
dikembangkan oleh Slavin, merupakan
salah satu tipe cooperative learning
yang menekankan interaksi diantara
siswa untuk saling memotivasi dan
saling membantu dalam menguasai

materi dan pencapaian prestasi secara maksimal, dan juga merupakan salah satu metode atau pendekatan dalam pembelajaran kooperatif yang sederhana dan baik untuk guru yang baru mulai menggunakan pendekatan kooperatif dalam kelas. Slavin dalam (Rusman, 2012) mengatakan bahwa model STAD (Student Team Achievement Division) merupakan variasi pembelajaran kooperatif yang paling banyak diteliti. Model ini juga sangat mudah diadaptasi, telah digunakan dalam berbagai macam disiplin ilmu pada tingkat sekolah dasar sampai perguruan tinggi juga merupakan suatu metode pembelajaran kooperatif yang efektif untuk diterapkan dalam pembelajaran.

Adapun Model Pembelajaran Kooperatif Tipe NHT (Numbered Head Together) dikembangkan oleh Spencer Kagan, 1992. Model ini memberikan kesempatan kepada peserta didik untuk saling membagikan ide-ide dan mempertimbangkan jawaban yang paling tepat. Selain itu, model ini juga mendorong peserta didik untuk meningkatkan semangat kerja sama mereka. model ini bisa digunakan dalam semua mata pelajaran dan untuk semua tingkatan usia anak didik (Lie, 2010)

Pembelajaran kooperatif tipe NHT (Numbered Heads Together) merupakan salah satu tipe pembelajaran kooperatif yang menekankan pada struktur khusus yang dirancang untuk mempengaruhi pola interaksi siswa dan memiliki tujuan untuk meningkatkan penguasaan akademik (Hosnan, 2014). Model pembelajaran ini mengakomodasikan peningkatan intensitas diskusi antar kelompok, kebersamaan, kolaborasi 
dan kualitas interaksi dalam kelompok, serta memudahkan penilaian. Model Pembelajaran kooperatif tipe NHT ((Numbered Heads Together) juga merupakan sebuah varian dari group discussion, pembelokannya yaitu di sana peserta didik yang mewakili kelompoknya tetapi sebelumnya tidak diberi tahu siapa yang akan menjadi wakil kelompok tersebut. Pembelokan tersebut memastikan keterlibatan total dari semua peserta didik (Tampubolon, 2014).

Model pembelajaran kooperatif dikembangkan untuk mencapai hasil belajar berupa prestasi akademik, toleransi, menerima keragaman, dan pengembangan ketrampilan sosial. Dalam mencapai hasil belajar dalam hal ini adalah kemampuan membaca pemahaman (Fahmul Qira'ah) peserta didik dituntut untuk berpikir kritis terhadap teks bacaan yang disajikan. Sebab berpikir kritis juga menjadi satu faktor yang menentukan hasil belajar peserta didik.

Berpikir kritis menurut (Egen, 2012) menyatakan bahwa merupakan "an individual's ability and inclination to make and asses conclusions based on evidence", yaitu kemampuan dan kecenderungan individu untuk membuat dan menilai kesimpulan berdasarkan bukti yang ada. Titik berat dari Eggen dan Kauchak adalah bukti, sehingga bukti menjadi penting dalam kemampuan berpikir kritis, karena bukti akan memandu seseorang dalam menentukan kecenderungan atau keputusan.

Berpikir dapat dirumuskan dalam aktivitas-aktivitas kritis, seperti : (1) mencari jawaban yang jelas dari setiap pertanyaan, (2) mencari alasan atau argumen, (3) berusaha mengetahui informasi dengan tepat, (4) memakai sumber yang memiliki kredibilitas dan menyebutkannya, (5) memperhatikan situasi dan kondisi secara keseluruhan, (6) berusaha tetap relevan dengan ide utama, (7) memahami tujuan yang asli dan mendasar, (8) mencari alternatif jawaban, (9) bersikap dan berpikir terbuka, (10) mengambil sikap ketika ada bukti yang cukup, (11) mencari penjelasan sebanyak mungkin, (12) bersikap secara sistematis dan teratur (Ennis, 2011). Disamping itu, terdapat enam unsur dasar dalam berpikir kritis menurut Ennis yaitu fokus (focus), alasan (reason), kesimpulan (inference), situasi (sitution), kejelasan (clarity), dan pemeriksaan secara menyeluruh (overview) (Ennis, 2011).

Berdasarkan perumusan masalah tujuan penelitian ini secara rinci adalah untuk mengetahui: 1) Perbedaan kemampuan membaca pemahaman (fahmul qira'ah) bahasa Arab peserta didik yang mengikuti model pembelajaran kooperatif tipe STAD dengan peserta didik yang mengikuti model pembelajaran kooperatif tipe NHT. 2) Pengaruh interaksi antara model pembelajaran dengan kemampuan berpikir kritis terhadap kemampuan membaca pemahaman (fahmul qira'ah) bahasa Arab peserta didik. 3) Perbedaan kemampuan membaca pemahaman (fahmul qira'ah) bahasa Arab peserta didik yang mengikuti model pembelajaran kooperatif tipe STAD dengan kemampuan berpikir kritis tinggi dan peserta didik yang mengikuti model pembelajaran kooperatif tipe NHT dengan kemampuan berpikir kritis tinggi. 4) Perbedaan kemampuan membaca pemahaman (fahmul qira'ah) bahasa Arab peserta didik yang mengikuti model pembelajaran 
kooperatif tipe STAD dengan kemampuan berpikir kritis rendah dan peserta didik yang mengikuti model pembelajaran kooperatif tipe NHT dengan memiliki kemampuan berpikir kritis rendah.

\section{METODE}

Penelitian ini dilakukan di MDT Shibyanul Muslimin Jakarta dikelas IV hal ini didasarkan pada pertimbangan bahwa peseta didik di MDT Shibyanul Muslimin Jakarta terutama kelas IV membutuhkan model pembelajaran yang menarik ditinjau dari perbedaan kemampuan berfikir peseta didik yang diharapkan mampu mempengaruhi kemampuan membaca pemahaman (fahmul qira'ah) bahasa Arab lebih tinggi.

Metode yang digunakan dalam penelitian ini adalah Metode eksperimen dengan treatment by level $2 x 2$. Gay dalam (Emzir, 2011) menyatakan bahwa Metode eksperimen adalah Metode yang digunakan untuk menguji hipotesis menyangkut hubungan sebab akibat. Peneliti memanipulasi paling sedikit satu variabel mengontrol variabel lain yang relevan, dan mengobservasi pengaruhnya terhadap satu atau lebih variabel terikat.

\footnotetext{
Masrun dalam (Sugiyono, 2013) mengatakan bahwa dalam perhitungan sampel yaitu: (1) Setiap kelas ditetapkan $27 \%$ dari urutan teratas sebagai kelompok kemampuan berfikir kreatif tinggi dan (2) $27 \%$ dari urutan terbawah dengan kemampuan berfikir kreatif rendah.
}

Populasi dalam penelitian ini adalah peseta didik kelas IV MDT Shibyanul Muslimin Jakarta pada tahun pelajaran 2019-2020 kelas IV terdiri dari 4 kelas yaitu IV A, IV B, IV C, IV D yang setiap kelas berjumlah 30 peserta didik maka keseluruhan jumlah kelas IV berjumlah 120 peserta didik. Adapun cara menetukan sampel yang akan diteliti dengan menggunakan teknik random sampling untuk memilih kelas eksperimen dan kelas kontrol, sehingga terpilih kelas eksperimen IV D dan kelas kontrol terpilih kelas IV C.

Peserta didik yang terpilih sebagai sampel penelitian, dari kelas kontrol maupun eksperimen, diberikan instrument berupa kuesioner kemampuan berpikir kritis untuk mengetahui mana kelompok peseta didik yang memiliki kemampuan berpikir kritis tinggi dan kelompok peseta didik yang memiliki kemampuan berpikir kritis rendah.

\section{Guilford dalam (Arikunto :} 2013) menjelaskan bahwa skor yang diperoleh dari tes tersebut kemudian diperingkat dari skor tertinggi sampai skor terendah kemudian diambil sebanyak $27 \%$ kelompok atas dinyatakan sebagai kelompok berpikir kritis tinggi dan $27 \%$ kelompok bawah yang dinyatakan sebagai kelompok berpikir kritis rendah. Setiap kelas memiliki jumlah peseta didik 30 orang, dengan demikian diperoleh hasil penentuan sampel $27 \%$ dari 30 peseta didik adalah 8 peseta didik sehingga jumlah sampel dari masing-masing kelas perlakuan adalah 16 peseta didik, 8 peseta didik yang memiliki kemampuan berpikir kritis tinggi dan 8 peseta didik yang memiliki kemampuan berpikir kritis rendah, yang menggunakan model 
pembelajaran kooperatif tipe STAD demikian juga dengan kelompok peseta didik yang menggunakan model pembelajaran kooperatif tipe NHT, diperoleh hasil 8 peseta didik memiliki kemampuan berpikir kritis tinggi dan 8 peseta didik memiliki kemampuan berpikir kritis rendah.

Teknik analisis menggunakan teknik analisis variansi dua jalur. Pengujian persyaratan analisis menggunakan uji normalitas dan uji homogenitas. Pengujian persyaratan normalitas digunakan untuk menguji apakah sampel berasal dan populasi yang berdistribusi normal atau tidak. Uji normalitas data dilakukan dengan teknik uji Liliefors. Uji homogenitas dilakukan untuk mengetahui apakah populasi penelitian mempunyai variasi yang homogen. Uji homogenitas dalam penelitian ini menggunakan uji Bartlett.

\section{HASIL DAN PEMBAHASAN}

\section{Hipotesis Pertama}

Terdapat

kemampuan membaca pemahaman (fahmul qira'ah) bahasa Arab yang signifikan antara peserta didik yang mengikuti model pembelajaran kooperatif tipe STAD dan peserta didik yang mengikuti model pembelajaran kooperatif tipe NHT.

Berdasarkan perhitungan Anava dua jalur diperoleh Fhitung untuk model pembelajaran sebesar 5, 288 sedangkan $F_{\text {tabel }}=4,20$ pada taraf nyatanya $\alpha=0,05$, karena nilai $F_{\text {hitung }}$ $>\mathrm{F}_{\text {tabel}}$, maka (Ho) ditolah dan $\mathrm{H} 1$ diterima artinya bahwa terdapat perbedaan kemampuan membaca pemahaman (fahmul qira'ah) bahasa Arab antara peserta didik yang mengikuti model pembelajaran kooperatif tipe STAD dan kooperatif tipe NHT.

Uji lanjut untuk Uji Tuckey menunjukan bahwa nilai $\mathrm{Q}_{\text {hitung }}=3,25$ yang lebih besar dari pada nilai $Q$ tabel $(0.05 ; 16 ; 2)=3,00$. Dengan demikian dapat disimpulkan bahwa kemampuan membaca pemahaman (fahmul qira'ah) bahasa Arab peserta didik yang belajar dengan mengikuti model pembelajaran kooperatif tipe STAD lebih lebih tinggi dari peserta didik yang belajar dengan mengikuti model pembelajaran kooperatif tipe NHT.

\section{Hipotesis Kedua}

Terdapat pengaruh interaksi antara penggunaan model pembelajaran dan kemampuan berpikir kritis terhadap kemampuan membaca pemahaman (fahmul qira'ah) bahasa Arab peserta didik.

Berdasarkan hasil perhitungan ANAVA dapat dilihat bahwa Fhitung untuk faktor interaksi yaitu 42, 952 lebih besar daripada Ftabel yaitu 4, 20 pada taraf nyata $\alpha=0,05$. Hal ini menunjukan bahwa terdapat pengaruh interaksi antara penggunaan model pembelajaran dan kemampuan berpikir kritis peserta didik terhadap kemampuan membaca pemahaman (fahmul qira'ah) bahasa Arab peserta didik. Dari data tersebut maka disimpulkan Ho ditolak dan $\mathrm{H} 1$ diterima.

\section{Uji Tuckey dilakukan untuk} melihat signifikansi yang hasilnya membuktikan bahwa ada pengaruh interaksi antara model pembelajaran dan kemampuan berpikir kritis 
terhadap kemampuan membaca pemahaman (fahmul qira'ah) bahasa Arab. Hal ini ditujukan dari hasil Qhitung $(\mathrm{A} 1 \mathrm{~B} 1$ dan $\mathrm{A} 2 \mathrm{~B} 2)=4,07>\mathrm{Qt}=3$, 00. Dengan demikian dapat disimpulkan bahwa terdapat pengaruh interaksi antara penggunaan model pembelajaran dengan kemampuan berpikir kritis terhadap kemampuan membaca pemahaman (fahmul qira'ah) bahasa Arab peserta didik.

\section{Hipotesis Ketiga}

Kemampuan membaca pemahaman (fahmul qira'ah) bahasa Arab peserta didik untuk kelompok berpikir kritis tinggi yang mengikuti model pembelajaran kooperatif tipe STAD dan model pembelajaran kooperatif tipe NHT. Nilai rerata dari kemampuan membaca pemahaman (fahmul qira'ah) bahasa Arab peserta didik dengan kemampuan berpikir kritis tinggi yang mengikuti model pembelajaran kooperatif tipe STAD $\left(\mathrm{A}_{1} \mathrm{~B}_{1}\right)$ adalah 34,13 sedangkan nilai rerata kemampuan membaca pemahaman (fahmul qira'ah) bahasa Arab dengan berpikir kritis tinggi yang mengikuti model pembelajaran kooperatif tipe NHT (A2B1) adalah 24, 50 yang kedua nilai ini kemudian dibandingkan dengan menggunakan Uji Tuckey .

Hasil tersebut diketahui bahwa Qhitung yaitu 8, 85>Q tabel yaitu 4,04 pada taraf signifikansinya $\boldsymbol{\alpha}=$ 0,05, dengan demikian maka dapat disimpulkan $\mathrm{H} 0$ ditolak dan $\mathrm{H} 1$ diterima yang berarti bahwa untuk peserta didik yang mempunyai kemampuan berpikir kritis tinggi terdapat perbedaan kemampuan membaca pemahaman (fahmul qira'ah) bahasa Arab dengan peserta didik yang mengikuti model pembelajaran kooperatif tipe NHT. Hipotesis Keempat

Perbedaan kemampuan membaca pemahaman (fahmul qira'ah) bahasa Arab peserta didik yang memiliki kemampuan berpikir kritis rendah yang mengikuti model pembelajaran kooperatif tipe STAD dan peserta didik yang mengikuti model pembelajaran kooperatif tipe NHT.

Nilai rerata kemampuan membaca pemahaman (fahmul qira'ah) bahasa Arab peserta didik dengan kemampuan berpikir kritis rendah yang menikuti model pembelajaran kooperatif tipe STAD (A1B2) adalah 26,38, sedangkan nilai rerata kemampuan membaca pemahaman (fahmul qira'ah) bahasa Arab peserta didik dengan kemampuan berpikir kritis rendah yang mengikuti model pembelajaran kooperatif tipe NHT (A2B2) adalah 31,00.

Hasil Uji Tuckey menunjukan bahwa Qhitung yaitu 8, 85 lebih besar daripada Qtabel yaitu 4,04 pada taraf signifikansinya $\boldsymbol{\alpha}=\mathbf{0 , 0 5}$, dengan demikian maka dapat disimpulkan $\mathrm{H} 0$ ditolak dan $\mathrm{H} 1$ diterima yang berarti bahwa kemampuan membaca pemahaman (fahmul qira'ah) bahasa Arab peserta didik yang mempunyai kemampuan berpikir kritis rendah yang mengikuti model pembelajaran kooperatif tipe STAD dan peserta didik yang mempunyai kemampuan berpikir kritis rendah yang mengikuti pembelajaran kooperatif tipe NHT terdapat perbedaan. Artinya bahwa peserta didik yang memiliki kemampuan berpikir kritis rendah lebih 
cocok diajar dengan model pembelajaran kooperatif tipe NHT.

Berdasarkan hasil analisis data diketahui bahwa hipotesis nol yang menyatakan tidak terdapat perbedaan signifikan antara kemampuan membaca pemahaman (fahmul qira'ah) bahasa Arab peserta didik MDT Shibyanul Muslimin Jakarta Kelas IV D yang diberikan model pembelajaran kooperatif tipe STAD ditolak. Jika dianalisis lebih jauh dengan menggunakan Uji Tuckey ternyata penggunaan model pembelajaran kooperatif tipe STAD memiliki efek yang lebih tinggi bagi kemampuan membaca pemahaman (fahmul qira'ah) bahasa Arab peserta didik. Peserta didik memperoleh kemampuan membaca pemahaman (fahmul qira'ah) bahasa Arab yang lebih baik jika diberikan model pembelajaran kooperatif tipe STAD.

Hasil pengujian hipotesis yang pertama tersebut menunjukan bahwa terdapat perbedaan yang signifikan pada kemampuan membaca pemahaman (fahmul qira'ah) bahasa Arab peserta didik kelas IV yang mengikuti model pembelajaran kooperatif tipe STAD dan kooperatif tipe NHT. Secara keseluruhan kemampuan membaca pemahaman (fahmul qira'ah) bahasa Arab peserta didik kelas IV yang mengikuti model pemebelajaran kooperatif tipe STAD lebih tinggi daripada peserta didik yang mengikuti model pembelajaran kooperatif tipe NHT. Model kooperatif tipe STAD dianggap lebih mampu meningkatkan kemampuan berpikir kritis peserta didik dengan adanya analogi-analogi dalam proses pembelajaran kooperatif tipe STAD menstimulus peserta didik sehingga mampu menciptakan ide baru dalam proses pemecahan masalah. Hasil $U j i$ Tuckey untuk hipotesis kedua berhasil menolak hipotesis nol yang menyatakan bahwa tidak terdapat pengaruh interaksi antara penggunaan model pembelajaran dan kemampuan berpikir kritis peserta didik terhadap kemampuan membaca pemahaman (fahmul qira'ah) bahasa Arab peserta didik.

Hasil uji hipotesis ketiga menerima hipotesis yang menyatakan bahwa untuk peserta didik yang mempunyai kemampuan berpikir kritis tinggi lebih baik menggunakan model pembelajaran kooperatif tipe STAD, dan untuk peserta didik yang memiliki kemampuan berpikir kritis rendah lebih baik menggunakan model pembelajaran kooperatif tipe NHT.

Model pembelajaran kooperatif tipe STAD lebih tepat digunakan oleh peserta didik yang memiliki kemampuan berpikir kritis tinggi karena dalam proses pembelajaran dengan menggunakan model pembelajaran kooperatif tipe STAD peserta didik diberikan kesempatan untuk belajar dengan cara yang menyenangkan sehingga peserta didik mampu mengemukakan gagasangagasan baru dan peserta didik dapat lebih santai dalam menyelesaikan tugas-tugasnya dengan membuat perbandingan-perbandingan.

Model pembelajaran kooperatif tipe STAD mampu mengarahkan peserta didik yang memiliki kemampuan berpikir kritis tinggi agar dapat menemukan analogi-analogi dalam memecahkan berbagai permasalahan. Pada proses pemecahan 
masalahnya peserta didik diberikan kesempatan untuk menciptakan ide baru dalam memandang sesuatu dari sudut pandang yang berbeda, proses belajar yang demikian akan mampu menigkatkan kemampuan membaca pemahaman (fahmul qira'ah) bahasa Arab peserta didik, sehingga dapat disimpulkan bahwa model pembelajaran kooperatif tipe STAD baik digunakan untuk peserta didik yang memiliki kemampuan berpikir kritis tinggi dan model pembelajaran kooperatif tipe NHT baik digunakan oleh peserta didik yang memiliki kemampuan berpikir kritis rendah.

Hasil pengujian hipotesis keempat menolak hipotesis nol yang menyatakan bahwa tidak terdapat perbedaan kemampuan membaca pemahaman (fahmul qira'ah) bahasa Arab antara peserta didik yang memiliki kemampuan berpikir kritis rendah yang mengikuti model pembelajar kooperatif tipe STAD dengan peserta didik yang memiliki kemampuan berpikir kritis rendah yang mengikuti model pembelajaran kooperatif tipe NHT.

Hasil analisis Uji Tuckey peserta didik yang memiliki kemampuan berpikir kritis rendah apabila mengikuti model pembelajaran kooperatif tipe STAD kemampuan membaca pemahaman (fahmul qira'ah) bahasa Arab lebih rendah dari peserta didik yang mengikuti model pembelajaran kooperatif tipe NHT. Hal ini disebabkan karena dalam pembelajaran dengan menggunakan model pembelajaran kooperatif tipe STAD peserta didik dituntut untuk dapat mengaplikasikan ide-ide baru, memberikan banyak saran untuk melakukan berbagai hal, menyajikan suatu konsep dengan sudut pandang yang berbeda, memecahkan masalah secara detai, dan mampu mengemukakan bermacam-macam pemecahan atau pendekatan terhadap masalah.

Peserta didik yang memiliki kemampuan berpikir kritis rendah lebih cocok mengikuti model pembelajaran kooperatif tipe NHT dikarenakan model ini tidak menuntut peserta didik untuk mengungkapkan gagasangagasan baru dari sudut pandang yang berbeda secara detail, model ini lebih menekankan pada kerjasama kelompok. Dalam penerapan model ini pendidik sebelumnya telah mempersiapkan beberapa tema yang akan dibahas oleh peserta didik yang kemudian didiskusikan oleh masingmasing kelompok, sehingga dalam prosesnya pendidik telah memfasilitasi peserta didik dengan baik sehingga hal ini kurang menuntut peserta didik untuk berpikir kritis karena tema-tema dalam pembahasan telah disiapkan oleh pendidik.

Pembelajaran yang telah difasilitasi dengan baik oleh pendidik akan lebih mudah diikuti oleh peserta didik yang memiliki kemampuan berpikir kritis rendah karena peserta didik tidak dituntut untuk mengeksplore kemampuan dalam menemukan gagasan-gagasan baru dan dalam proses pembelajarannya peserta didik tidak terlalu dilibatkan cukup mendengarkan arahan yang disampaikan oleh pendidik sehingga proses pembelajaran seperti ini lebih tepat untuk peserta didik yang memiliki kemampuan berpikir kritis rendah. 


\section{KESIMPULAN DAN SARAN}

\section{Kesimpulan}

1. Hasil penelitian menunjukan bahwa kemampuan membaca pemahaman (fahmul qira'ah) bahasa Arab peserta didik yang mengikuti model pembelajaran kooperatif tipe STAD lebih tinggi dari peserta didik yang mengkuti model pembelajaran kooperatif tipe NHT.

2. Terdapat pengaruh interaksi antara model pembelajaran dan kemampuan berpikir kritis peserta didik terhadap kemampuan membaca pemahaman (fahmul qira'ah) bahasa Arab.

3. Kemampuan membaca pemahaman (fahmul qira'ah) bahasa Arab peserta didik yang mengikuti model pembelajaran kooperatif tipe STAD dengan kemampuan berpikir kritis tinggi lebih tinggi dari peserta didik yang mengikuti model pembelajaran kooperatif tipe NHT dengan kemampuan berpikir kritis tinggi.

4. Kemampuan membaca pemahaman (fahmul qira'ah) bahasa Arab peserta didik yang mengikuti model pembelajaran kooperatif tipe STAD dengan kemampuan berpikir kritis rendah lebih rendah dari peserta didik yang mengikuti model pembelajaran kooperatif tipe NHT dengan kemampuan berpikir kritis rendah.

\section{Saran}

Berdasarkan hasil penelitian yang telah dilakukan maka dapat disimpulkan beberapa saran sebagai berikut:
1. Bagi pendidik dapat menggunakan model pembelajaran kooperatif tipe STAD untuk meningkatkan kemampuan membaca pemahaman (fahmul qira'ah) peserta didik di MDT Shibyanul Muslimin Jakarta Utara.

2. Bagi kepala sekolah hendaknya memfasilitasi pendidik dengan memberikan pelatihan bagi yang belum memahami model pembelajaran kooperatif.

3. Bagi peserta didik yang memiliki kemampuan berpikir kritis tinggi pendidik dapat menggunakan model pembelajaran kooperatif tipe STAD sebagai alternatif untuk mengmbangkan kreativitas

\section{DAFTAR PUSTAKA}

Aizid, R. (2011). Bisa Baca Secepat

Kilat (Super Quick Reading).

Yogyakarta: Buku Biru.

Alek, d. (2010). Bahasa Indonesia untuk Perguruan Tinggi. Jakarta: Kencana Prenada Media Group.

Arikunto, S. (2013). Prosedur Penelitian Dalam Pendekatan Praktek. Jakarta: Rhineka Cipta.

Egen, P. d. (2012). Strategi dan Pembelajaran. Yogyakarta: Indeks.

Emzir. (2011). Metode Penelitian Kuantitatif dan Kualitatif. Jakarta: PT. Grafindo Persada.

Ennis, R. (2011). The Nature of Critical Thinking: An Outline of Critikal Thinking Dispositions and Abilities. Chicago: University of Illinois. 
Hosnan, M. (2014). Pendekatan

Saintifik dan Kontekstual dalam

Pembelajaran Abad 21. Bogor:

Ghalia Indonesia.

Lie, A. (2010). Cooperative Learning Mempraktikkan Cooperative Learning di Ruang-Ruang Kelas. Jakarta: Grasindo.

Purwanto, N. (2010). Prinsip-Prinsip dan Teknik Evaluasi Pengajaran. Bandung: Remaja Rosda Karya.

Rusman. (2012). Model-model Pembelajaran : mengembangkan profesionalisme guru . Jakarta: PT Raja Grafindo Persada.

Sudijono, A. (2011). Pengantar Evaluasi Pendidikan. Jakarta: Rajawali Pers.

Sugiyono. (2013). Pendekatan

Penelitian Pendidiikan: Pendekatan Kuantitatif, Kualitatif, dan $R \& D$. Bandung: Alfabeta.

Tampubolon, S. (2014). Penelitian Tindakan Kelas Sebagai Pengembangan Profesi Pendidik dan Keilmuan. Jakarta: Erlangga. 